\title{
Interleukin-1 Receptor Antagonist Protein
}

National Cancer Institute

\section{Source}

National Cancer Institute. Interleukin-1 Receptor Antagonist Protein. NCI Thesaurus. Code C98166.

Interleukin-1 receptor antagonist protein (177 aa, $20 \mathrm{kDa}$ ) is encoded by the human IL1RN gene. This protein is involved in the inhibition of the interaction between interleukin-1 and its receptor. 